\title{
A multicenter study on experience of 13 tertiary hospitals in Turkey in patients with infective endocarditis
}

\section{Türkiye'de 13, üçüncü basamak hastanenin katıldı̆̆ı çok merkezli enfektif endokardit çalışması}

\section{Mehmet Ali Elbey, Serkan Akdağ'1, Mehmet Emin Kalkan², Mehmet G. Kaya ${ }^{3}$, M. Raşit Sayın ${ }^{4}$, Hekim Karapınar $^{5}$, Serkan Bulur ${ }^{6}$, Taner Ulus ${ }^{7}$, M. Ata Akll, Hatice Köprü Elbey*, Abdurrahman Akyüz}

Department of Cardiology and *ophthalmology, Faculty of Medicine, Dicle University, Diyarbakır-Turkey

${ }^{1}$ Department of Cardiology, Faculty of Medicine, Yüuzüncü Yıl University, Van-Turkey

${ }^{2}$ Clinic of Cardiology, Kartal Koşuyolu Education and Research Hospital, Istanbul-Turkey

${ }^{3}$ Department of Cardiology, Faculty of Medicine, Erciyes Universily, Kayseri-Furkey

${ }^{4}$ Department of Cardiology, Faculty of Medicine, Bülent Ecevit University, Zonguldak-Turkey

5 Department of Cardiology, Faculty of Medicine, Cumhuriyet University, Sivas-Turkey

${ }^{6}$ Department of Cardiology, Faculty of:Medicine, Düzce University, Düzce-Turkey

7Department of Cardiology, Faculty of Medicine, Eskişehir Osmangazi University, Eskişehir-Turkey

\section{ABSTRACT}

Objective: The aim of this retrospective multicenter study was to investigate the clinical manifestations, microbiological profile, echocardiographic findings and management strategies of infective endocarditis (IE) in Turkey.

Methods: The study population consisted of 248 Turkish patients with IE treated at 13 major hospitals in Turkey from 2005 to 2012 retrospectively. All hospitals are tertiary referral centers, which receive patients from surrounding hospitals. Data were collected from the medical files of all patients hospitalized with IE diagnosed according to modified Duke Criteria.

Results: One hundred thirty seven of the patients were males. Native valves were involved in 158 patients while in 75 participants there was prosthetic valve endocarditis. Vegetations were detected in 223 patients $(89 \%)$ and 52 patients had multiple vegetations. Mitral valve was the most common site of vegetation (43\%). The most common valvular pathology was mitral regurgitation. The most common predisposing factor was rheumatic valvular disease (28\%). Positive culture rate was $65 \%$. Staphylococci were the most frequent causative microorganisms isolated $(29 \%)$ followed by enterococci $(11 \%)$. In-hospital mortality rate was $33 \%$.

Conclusions: Compared to IE in developed countries younger age, higher prevalence of rheumatic heart disease, more frequent enterococci infection and higher rates of culture negativity were other important aspects of IE epidemiology in Turkey.

(Anadolu Kardiyol Derg 2013; 13: 523-7)

Key words: Infective endocarditis, epidemiology, echocardiography, blood culture, vegetation

ÖZET

Amaç: Bu çok merkezli geriye dönük çalışmada Türkiye'de infektif endokarditin klinik ve mikrobiyolojik özellikleri, ekokardiyografik bulguları ve tedavi stratejisinin belirlenmesi amaçlanmıştır.

Yöntemler: Çalışmaya alınan grup 2005-2012 tarihleri arasında Türkiye'de 13 merkezde infektif endokardit tedavisi alan, retrospektif olarak 248 hastayı içermektedir. Tüm merkezler çevre hastanelerden hasta kabul eden üçüncü basamak hastaneler idi. Veriler, modifiye Duke kriterlerine göre infektif endokardit tanısı ile yatırılan hastaların arşiv bilgilerinden alınmıştır.

Bulgular: Hastaların yüz otuz yedisi erkek idi. Hastalardan yüz elli sekizinde doğal kapak, yetmiş beşinde protez kapak endokarditi mevcuttu. Iki yüz yirmi üç hastada (\%89) vejetasyon mevcuttu ve 52 hastada vejetasyon birden fazla sayıda idi. Vejetasyon en sık mitral kapak (\%43) konumunda bulundu. En sık görülen kapak hastalığı mitral yetersizliğiydi. En sık izlenen predispozan faktör romatizmal kapak hastalığı idi (\%28). Pozitif kan kültürü \%65 oranında saptandı. En sık izole edilen sorumlu organizma Staphylococcus aureus idi (\%29). Hastane içi ölüm hızı \%33 olarak bulundu.

Sonuç: Batılı ülkelerle karşılaştırıldı̆ında ülkemizde infektif endokardit epidemiyolojisinin en önemli farklılıkları genç yaş, yüksek romatizmal kalp hastalığı prevelansı, sık enterokokal enfeksiyon ve yüksek kültür negatif sıklı̆ııır. (Anadolu Kardiyol Derg 2013; 13: 523-7)

Anahtar kelimeler: Infektif endokardit, epidemiyoloji, ekokardiyografi, kan kültürü, vejetasyon

Address for Correspondence/Yazışma Adresi: Dr. Mehmet Ali Elbey, Dicle Üniversitesi Tıp Fakültesi, Kardiyoloji Anabilim Dalı, 21280, Diyarbakır-Türkiye Phone: +904122488001 Fax: +90 4122488523 E-mail: elbeymali@hotmail.com

Accepted Date/Kabul Tarihi: 09.10.2012 Available Online Date/Çevrimiçi Yayın Tarihi: 04.07.2013

(C) Telif Hakkı 2013 AVES Yayıncılik Ltd. Şti. - Makale metnine unww.anakarder.com web sayfasından ulaş/labilir. (C) Copyright 2013 by AVES Yayincllk Ltd. - Available on-line at www.anakarder.com doi:10.5152/akd.2013.172 


\section{Introduction}

Despite great medical progress, infective endocarditis (IE) remains a life-threatening condition with a high mortality rate $(1,2)$. In developed countries, the epidemiological features of IE are changing as a result of new predisposing factors, higher frequency of nosocomial cases and increasing longevity $(3,4)$. New developments in the diagnosis and management of IE have influenced the pattern of disease seen in developed countries, particularly as related to early surgical intervention and reduced mortality (5-8):

Although rheumatic heart disease is still a major risk factor for IE in most developing countries, acute rheumatic fever has declired sharply and degenerative valvular lesions have become the most frequent anatomic abnormalities predisposing to infection in the west $(5,9)$. IE is frequently associated with rheumatic valvular disease resulting in high morbidity and mortality in Turkev (10). In fact, most studies on IE from the developing world with few exceptions are single center studies $(11,12)$.

Tre aim of this multicenter study was to investigate the clinical manifestations, microbiological profile, echocardiograph ic findings and management strategies of IE in Turkey.

Table 1. Demographic characteristics, clinical signs, symptoms and biochemical variables on admission

\begin{tabular}{|c|c|c|}
\hline Variables & Frequency & $\%$ \\
\hline Gender (M/F) & $137 / 111$ & $55 / 45$ \\
\hline \multicolumn{3}{|l|}{ Presenting symptoms } \\
\hline Fever & 189 & 76.2 \\
\hline Fatigue & 128 & 51.6 \\
\hline Dy'spnea & 122 & 49.2 \\
\hline Gastrointestinal symptoms & 78 & 31.5 \\
\hline Crills & 43 & 17.3 \\
\hline Lass of weight & 37 & 14.9 \\
\hline Muscle and joint symptoms & 13 & 5.2 \\
\hline Skin lesions & 6 & 2.4 \\
\hline NYH.A III/ IV & 126 & 51 \\
\hline Diabetes mellitus & 35 & 14 \\
\hline Previous IE & 7 & 3 \\
\hline Atrial fibrillation & 33 & 13 \\
\hline Systolic blood pressure, $\mathrm{mmHg}$ & $113 \pm 16$ & \\
\hline Diastolic blood pressure, $\mathrm{mmHg}$ & $70 \pm 10$ & \\
\hline Mean heart rate, bpm & $90 \pm 14$ & \\
\hline Hemoglobin, $\mathrm{g} / \mathrm{dL}$ & $11 \pm 2.2$ & \\
\hline Whit s blood cell, $\mathrm{n} / \mathrm{mL}$ & $15367 \pm 7428$ & \\
\hline Sedimentation rate, $\mathrm{mm} / \mathrm{hou}$ ir & $66 \pm 27$ & \\
\hline C- reactive protein, $\mathrm{mg} / \mathrm{dL}$ & $71 \pm 61$ & \\
\hline Creatinine, mg/dL & $1.43 \pm 0.76$ & \\
\hline
\end{tabular}

\section{Methods}

\section{Study design}

The study was designed as a retrospective observational multicenter trial.

\section{Study population}

The study population consisted of 248 consecutive Turkish patients with IE treated at 13 major hospitals in seven geographical areas of Turkey from 2005 to 2012 respectively. All hospitals are tertiary referral centers, which receive patients from surrounding hospitals. These hospitals were located in different cities throughout Turkey. We analyzed the medical files of all patients hospitalized with the diagnosis of IE. Inclusion criteria were definite IE, according to modified Duke Criteria (13). All patients had undergone transthoracic echocardiography (TTE) on admission and at regular intervals thereafter or whenever there was a change in the clinical status. Echocardiographic data included routine parameters and presence, number, maximal diameter and mobility of any vegetation. Transesophageal echocardiography (TEE) was considered in patients with a high clinical suspicion of IE with a nondiagnostic TTE and in those with a suspected mechanical complication. Patients with possible IE were excluded.

The study was approved by the local Medical Ethics Committee.

\section{Data collection}

Data on demographic characteristics, age, sex, underlying heart disease, presenting signs and symptoms, diabetes mellitus and other co-morbidities, results of laboratory and microbiological investigations, echocardiographic findings, treatment given during hospitalization, surgical requirements, cardiac and extracardiac complications were collected. The patients were also analyzed for factors associated with recurrent episodes of IE. The antibiotic regimen, aspects related to the surgical approach, and in-hospital outcome were also recorded. Complete blood count, C-reactive protein, erythrocyte sedimentation rates, serum chemistry, and urine analysis comprised the routine laboratory investigations that were recorded.

\section{Statistical analysis}

Statistical Package for Social Sciences software (SPSS 12, Chicago, IL, USA) was used for analysis. Descriptive statistics are presented as mean \pm standard deviation or percentages.

\section{Results}

Baseline characteristics of the patients are shown in Table 1. The mean age of patients was $47 \pm 18$ years (range 13-87). One hundred thirty seven of the patients were males. The most common symptom at presentation was fever $189(76 \%)$. Native valves endocarditis (NVE) was involved in 158 patients while in 75 par- 
Table 2. Echocardiographic manifestations of the patients with IE

\begin{tabular}{|l|c|c|}
\hline Variables & Frequency & $\%$ \\
\hline Native valve endocarditis & 158 & 64 \\
\hline Rheumatic heart disease & 69 & 28 \\
\hline Degenerative heart disease & 57 & 23 \\
\hline Congenital heart disease & 18 & 7 \\
\hline Mitral valve prolapsus & 9 & 4 \\
\hline Prosthetic valve endocarditis & 75 & 30 \\
\hline Pacemaker endocarditis & 15 & 6 \\
\hline Vegetations & 223 & 89 \\
\hline Multiple & 52 & 21 \\
\hline Mobile & 150 & 60 \\
\hline Diameter, mm & $4.4 \pm 4.9$ & \\
\hline Aortic regurgitation & 82 & 33 \\
\hline Mitral regurgitation & 142 & 56 \\
\hline Ejection fraction & $53 \pm 11$ & \\
\hline Continuous variables were are represented as mean \pm SD & \\
\hline
\end{tabular}

Table 3. Sites of vegetations detected by echocardiography in 248 patients with infective endocarditis

\begin{tabular}{|l|c|}
\hline Site & Number of patients (\%) \\
\hline Mitral valve & $107(43.1)$ \\
\hline Aortic valve & $79(31.9)$ \\
\hline Mitral+aortic valves & $23(9.3)$ \\
\hline Tricuspid valve & $22(8.9)$ \\
\hline Pulmonic valve & $6(2.4)$ \\
\hline Bicuspid aortic valve & $5(2)$ \\
\hline Tetralogy of Fallot & $5(2)$ \\
\hline Ventricular septal defect & $4(1.6)$ \\
\hline Aortic coarctation+Ventricular septal defect & 1 \\
\hline Atrial septal defect & 1 \\
\hline Hypertrophic cardiomyopathy & 1 \\
\hline Patent ductus arteriosus & 1 \\
\hline No vegetations on echocardiogram & $23(10.1)$ \\
\hline
\end{tabular}

ticipants there was prosthetic valve endocarditis (PVE) (Table 2). Seven of PVE were early PVE (onset of clinical manifestations within 12 months from valvular heart surgeryl, the other 68 of PVE were late PVE (onset of clinical manifestations later than 12 months from surgery). The remaining 15 patients had pacemaker endocarditis. Vegetations were detected in 223 patients $(89 \%)$ and 52 patients had multiple vegetations. The most common valvular pathology was mitral regurgitation, which was detected in 142 patients $(56 \%)$. The most common predisposing factors were rheumatic valvular disease $(n=69,28 \%)$. Mitral valve was the most common site of vegetation; 107 patients $(43 \%)$ which were followed by the aortic valve in 77 patients $(32 \%)$ and both mitral and aortic valves in 23 patients $(9 \%$ ) (Table 3).
Table 4. Distribution of causative microorganisms isolated from blood cultures in patients with infective endocarditis

\begin{tabular}{|l|c|}
\hline Organism & Number of patients (\%) \\
\hline Staphylococci & $73(29)$ \\
\hline Staphylococcus aureus & $53(21)$ \\
\hline MRSA & 15 \\
\hline MSSA & 11 \\
\hline Coagulase-negative & $16(6)$ \\
\hline Staphylococcus epidermidis & $4(2)$ \\
\hline Enterococcus & $28(11)$ \\
\hline Streptococci & $27(11)$ \\
\hline Viridans streptococci & 22 \\
\hline Streptococcus bovis & 1 \\
\hline Other streptococcal species & 4 \\
\hline Gram-negative organisms & $25(10)$ \\
\hline Brucella & $12(5)$ \\
\hline P. aeruginosa & 3 \\
\hline E. coli & $4(2)$ \\
\hline HACEK group & 5 \\
\hline Klebsiella spp. & 1 \\
\hline Candida albicans & 248 \\
\hline No growth on culture & $93(37.5)$ \\
\hline Total & \\
\hline MRSA - methicillin-resistant S. aureus, MSSA - methicillin-sensitive S. aureus \\
\hline
\end{tabular}

All patients had blood culture studies, but only $156(62 \%)$ had positive blood cultures for bacteremia. Staphylococci were the most frequent causative microorganisms isolated in both NVE $(n=45,28 \%)$ and PVE $(n=23,30 \%)$ cases, with an overall involvement of 68 cases $(27 \%)$ (Table 4). Methicillin-resistant staphylococci were isolated in 15 patients. Streptococci were isolated in $27(10 \%)$ of subjects with positive blood cultures followed by gram-negative microorganisms in eleven patients. Enterococcus endocarditis were found in 28 patients $(n=28,11.3 \%)$. Streptococci were the causative agents in 27 cases $(14.5 \%)$, mostly affected by $S$. viridans $(\mathrm{n}=22,8.9 \%)$. Fungal endocarditis (Candida albicans) was found in two patients.

Congestive heart failure was the most common complication, which was detected in 88 patients $(33 \%)$ during the disease course. Systemic embolism occurred in 71 patients $(29 \%)$. Septic shock occurred in 43 patients (17\%). The mean duration of antibiotic treatment was $28 \pm 18$ days. One hundred sixteen patients $(47 \%)$ had undergone combined medical and surgical treatment. Surgical intervention was performed in 86 patients $(54 \%)$ for NVE (total 158 patients) and in 30 patients $(40 \%$ ) for PVE (total 75 patients). Eighty-one patients died during hospital follow-up. In-hospital mortality rate was $33 \%$. Forty-seven patients $(36 \%)$ who were treated only with medical therapy died. The mortality rate was $29 \%$ (34 patients) with surgical treatment. The mortality rate was $57 \%$ in patients with early PVE and $31 \%$ in patients with late PVE. 


\section{Discussion}

Tre current study provides several important comprehensions into IE in tertiary hospitals in Turkey. Despite advances in diagnostic methods, antibiotic treatment, blood culture techniques and surgical therapy techniques, IE is still associated with high mortality rate. According to current study, rheumatic valvular disease remains the most common underlying heart disease of IE.

Several studies related to the epidemiology of infective endocarditis in Turkey have been published in the literature. However, these were single center studies and lack general trend and characteristics (14). For the first time, the present multicenter study has provided important data on the epidemiology, etiology, clinical, microbiology, treatment characteristics and the current perspective on IE in Turkey. Despite advances in diagnostic imaging methods, antibiotic therapy, blood culture techniques, and the surgical approach, IE is still associated with a high mortality rate. The most important finding of the current study was the relatively high rate of mortality. Despite higher rates of antibiotic therapy and surgical interventions, the overall in-hospital mortality rates for both native valve and prosthetic valve IE remained high (33\%), which is higher than that observed in other countries, including some developing countries $(1,5,15)$.

The epidemiologic characteristics of IE have shifted over the last decades in developed countries. In west populations, IE is commonly diagnosed in patients older than 50 years $(16,17)$. These changes are mainly being attributed to a number of factors including a marked reduction in the incidence of acute rheumatic disease and congenital heart disease, increase in cases of degenerative valvular disease, increasing patient longevity, increased use of invasive procedures and implanted medical devices (prosthetic valves, pacemaker, ICD and central vascular catheters etc.) $(5,12)$. In a recent study conducted by Leblebicioğlu et al. (14) from Turkey the mean age for IE was 45 years (112 adult patients), and in a study from Turkey by Çetinkaya et al. (10) the patients were under the age of 40 years (228 patients). In our study, the mean age of the patients was 47 years (range 13 to 87 years) and rheumatic heart disease still was the most common underlying heart disease for IE. Transtinoracic echocardiography and TEE was utilized in the vast majority of patients (95\%). The use of TEE was $37 \%$ in the whole population.

In the present study, positive culture rate was $65 \%$. The proportion of negative blood cultures was high in our study, which was $10 \%$ higher than the rates reported in recently published studies $(1,13)$. Culture negative endocarditis in the present study was more frequent in patients with IE mainly referred from peripheral hospitals, where a large spectrum of empiric antibiotic therapy had been administered before the definite diagnosis.

In previous studies, when blood cultures were positive, staphylococci and streptococci were the most commonly isolated causative agents of IE ( $36 \%$ and $35 \%$, respectively). These two microorganisms have been reported as main etiological agents in $13-49 \%$ and $20-63 \%$ of the cases with native valve endocarditis, respectively $(5,10,12)$. However, in our study cohort staphylococci and enterococci were the most frequently isolated causative agents in IE with the incidences of $29 \%$ and $11 \%$, respectively. The rate of enterococci infection was among the highest when compared with the literature data $(3-20 \%)(10$, $12,14,18)$. It is well known that enterococcal bacteremia is a serious infection, associated with mortality rates between $23 \%$ and $46 \%(19-22)$. But in our study mortality of enterococcal endocarditis was highest compared with other agents $(46 \%)$.

\section{Study limitations}

The main limitation of this study is its retrospective design. TEE was performed in only $37 \%$ of the cohort; which might have influenced the results related to the echocardiographic findings and their association with the outcome.

\section{Clinical implications}

The present study brings a new insight to our clinical practice. We hope these findings may be helpful to develop new strategies against IE in Turkey

\section{Conclusion}

The present study demonstrated that IE remains a severe disease with a high mortality rate. Younger age, higher prevalence of rheumatic heart disease, more frequent enterococci infection and higher rates of culture negativity were other important aspects of IE epidemiology in Turkey.

\section{Conflict of interest: None declared.}

Peer-review: Externally peer-reviewed.

Authorship contributions: Concept - M.A.E.; Design - M.A.E., M.E.K.; Supervision - M.A.E., S.A., M.G.K.; Resource - M.A.E.; Material - S.A., M.E.K.; Data collection\&/or Processing - M.R.S., H.K., S.B., T.U.; Analysis\&/or interpretation - M.A.E., M.G.K., M.A.A., M.E.K.; Literature search- M.A.E., M.E.K., H.K.E., A.A.; Writing - M.A.E.; Critical review - M.E.K., M.A.E.; Other - A.A., T.U., S.B., H.K.

\section{Acknowledgements}

\section{Collaborator list in alphabetical order}

1. Atatürk University School of Medicine, Department of Cardiology, Erzurum, Turkey (Enbiya Aksakal, Selim Topçu).

2. Bülent Ecevit University School of Medicine, Department of Cardiology, Zonguldak, Turkey (Mustafa Aydin, M. Raşit Sayın).

3. Cumhuriyet University School of Medicine, Department of Cardiology, Sivas, Turkey (Hekim Karapınar, Zekeriya Küçükdurmaz). 
4. Dicle University School of Medicine, Department of Cardiology, Diyarbakır, Turkey (Sıddık Ülgen, Sait Alan, Serdar Soydinç).

5. Düzce University School of Medicine, Department of Cardiology, Düzce, Turkey (Ismail Ekinözu, Yusuf Aslantaş).

6. Erciyes University School of Medicine, Department of Cardiology, Kayseri, Turkey (Mehmet G. Kaya, Mahmut Akpek).

7. Eskişehir Osmangazi University School of Medicine Department of Cardiology, Eskişehir, Turkey (Taner Ulus).

8. Gaziosman Paşa University School of Medicine, Department of Cardiology, Tokat, Turkey (Fatih Koç, Kerem Özbek).

9. Kahramanmaraş Sutçu Imam University School of Medicine, Department of Cardiology, Kahramanmaraş, Turkey (Cemal Tuncer, Gürkan Acar).

10. Kartal Koşuyolu Education and Research Hospital, Clinical Cardiology, Istanbul, Turkey (Ali Metin Esen).

11. Izmir Atatürk Education and Research Hospital, Clinical Cardiology, Izmir, Turkey (Nihan Kahya Eren).

12. Süleyman Demirel University School of Medicine, Department of Cardiology. Isparta, Turkey (Abdullah Doğan. Fatih Kahraman).

13. Yüzüncü YIl University School of Medicine, Department of Cardiology, Van, Turkey (Serkan Akdağ).

\section{References}

1. Nunes MC, Gelape CL, Ferrari TC. Profile of infective endocarditis at a tertiary care center in Brazil during a seven-year period: prognostic factors and in-hospital outcome. Int J Infect Dis 2010; 14: 394-8.

2. Murdoch DR, Corey GR, Hoen B, Miró JM, Fowler VG Jr, Bayer AS, et al. Clinical presentation, etiology, and outcome of infective endocarditis in the 21st century: the International Collaboration on EndocarditisProspective Cohort Study. Arch Intern Med 2009; 169: 463-73.

3. Martínez-Sellés M, Muñoz P, Estevez A, del Castillo R, GarcíaFernández MA, Rodríguez-Créixems $M$, et al. Long-term outcome of infective endocarditis in non-intravenous drug users. Mayo Clin Proc 2008; 83: 1213-7.

4. Wang A, Athan E, Pappas PA, Fowler VG Jr, Olaison L, Paré C, et al. Contemporary clinical profile and outcome of prosthetic valve endocarditis. International Collaboration on Endocarditis-Prospective Cohort Study Investigators. JAMA 2007; 297: 1354-61.

5. Tariq M, Alam M, Munir G, Khan MA, Smego RA Jr. Infective endocarditis: a five-year experience at a tertiary care hospital in Pakistan. Int J Infect Dis 2004; 8: 163-70.

6. Li JS, Sexton DJ, Mick N, Nettles R, Fowler VG Jr, Ryan T, et al. Proposed modifications to the Duke criteria for the diagnosis of infective endocarditis. Clin Infect Dis 2000; 30: 633-8.

7. Hoen B, Alla F, Selton-Suty C, Béguinot I, Bouvet A, Briançon S, et al. Changing profile of infective endocarditis: results of a 1-year survey in France. JAMA 2002; 288: 75-81.
8. Bouza E, Menasalvas A, Munoz P, Vasallo FJ, del Mar Moreno M, García Fernández MA. Infective endocarditis-a prospective study at the end of the twentieth century: new predisposing conditions, new etiologic agents, and still a high mortality. Medicine 2001; 80: 298-307.

9. Awadallah SM, Kavey RE, Byrum CJ, Smith FC, Kveselis DA, Blackman MS. The changing pattern of infective endocarditis in childhood. Am J Cardiol 1991; 68: 90-4.

10. Çetinkaya Y, Akova M, Akalın HE, Aş̧̧ığlu S, Hayran M, Uzun O, et al. A retrospective review of 228 episodes of infective endocarditis where rheumatic valvular disease is still common. Int $J$ Antimicrob Agents 2001; 18: 1-7.

1i. Ho HH, Siu CW, Yiu KH, Tse HF, Chui WH, Chow WH. Prosthetic valve endocarditis in a multicenter registry of Chinese patients. Asian Cardiovasc Thorac Ann 2010; 18: 430-4.

12. Letaief A, Boughzala E, Kaabia N, Ernez S, Abid F, Ben Chaabane T, et al. Epidemiology of infective endocarditis in Tunisia: a 10-year multicenter retrospective study. Int $\mathrm{J}$ Infect Dis 2007; 11: 430-3.

13. Ferreiros E, Nacinovich F, Casabé JH, Modenesi JC, Swieszkowski $\mathrm{S}$, Cortes C, et al. Epidemiologic, clinical and microbiologic profile of infective endocarditis in Argentina: a national survey. The endocarditis infecciosa en la Republica Argentina-2 (ElRA-2) Study. Am Heart J 2006; 151: 545-52.

14. Leblebicioğlu H, Yılmaz H, Taşova Y, Alp E, Saba R, Ceylan R, et al. Characteristics and analysis of risk factors for mortality in infective endocarditis. Eur J Epidemiol 2006; 21: 25-31.

15. Math RS, Sharma G, Kothari SS, Kalaivani M, Saxena A, Kumar AS, et al. Prospective study of infective endocarditis from a developing country. Am Heart J 2011; 162: 633-8.

16. Hill EE, Herijgers $P$, Claus $P$, Vanderschueren $S$, Herregods MC, Peetermans WE. Infective endocarditis: changing epidemiology and predictors of 6 -month mortality: a prospective cohort study. Eur Heart J 2007; 28: 196-203.

17. Tuğcu A, Yıldırımtürk 0, Baytaroğlu C, Kurtoğlu H, Köse O, Şener M, et al. Clinical spectrum, presentation, and risk factors for mortality in infective endocarditis: a review of 68 cases at a tertiary care center in Turkey. Turk Kardiyol Dern Ars 2009; 37: 9-18.

18. Lamas CC, Eykyn SJ. Suggested modifications to the Duke criteria for the clinical diagnosis of native valve and prosthetic valve endocarditis: analysis of 118 pathologically proven cases. Clin Infect Dis 1997; 25: 713-9.

19. Guerrero F, Goyenechea A, Verdejo C, Roblas RF, Gorgolas M. Enterococcal endocarditis on native and prosthetic valves: a review of clinical and prognostic factors with emphasis on hospital-acquired infections as a major determinant of outcome. Medicine 2007; 86: 363-77.

20. Martínez-Marcos FJ, Lomas-Cabezas JM, Hidalgo-Tenorio C, de la Torre-Lima J, Plata-Ciézar A, Reguera-Iglesias JM, et al. Enterococcal endocarditis: a multicenter study of 76 cases. Enferm Infecc Microbiol Clin 2009; 27: 571-9.

21. Anderson DJ, Murdoch DR, Sexton DJ, Reller LB, Stout JE, Cabell CH, et al. Risk factors for infective endocarditis in patients with enterococcal bacteremia: A case-control study. Infection 2004; 32: 72-7.

22. Patterson JE, Sweeney AH, Simms M, Carley N, Mangi R, Sabetta $\mathrm{J}$, et al. An analysis of 110 serious enterococcal infections. Epidemiology, antibiotic susceptibility, and outcome. Medicine 1995; 74: 191-200. 
Copyright of Anatolian Journal of Cardiology / Anadolu Kardiyoloji Dergisi is the property of Aves Yayincilik Ltd. STI and its content may not be copied or emailed to multiple sites or posted to a listserv without the copyright holder's express written permission. However, users may print, download, or email articles for individual use. 